\title{
Inconstitucionalidade da Lei de Abuso de Autoridade*
}

\author{
Ministro Carlos Ayres Britto**
}

\section{TEMA CENTRAL: O REGIME CONSTITUCIONAL DO PODER JUDICIÁRIO E DA FUNÇÃO JURISDICIONAL DO ESTADO}

- O Poder Judiciário, em face dos outros dois Poderes da República Federativa do Brasil, dos magistrados mesmos e do Sistema de Justiça

- A função judicante ou de prestação jurisdicional propriamente dita e a Lei Federal no 13.869, de 5 de setembro de 2019

Caráter do estudo: parecer jurídico

Consulentes: ASSOCIAÇÃO DOS JUÍZES FEDERAIS - AJUFE e ASSOCIAÇÃO DOS MAGISTRADOS BRASILEIROS - AMB

Parecerista: Carlos Ayres Britto

\footnotetext{
* Parecer gentilmente cedido pela Associação dos Juízes Federais (AJUFE) e pela Associação dos Magistrados Brasileiros (AMB) para publicação nesse periódico.

** Mestre e doutor pela Pontifícia Universidade Católica de São Paulo (PUC/SP), é membro da Academia Brasileira de Letras Jurídicas e da Academia Internacional de Direito e Economia.
} 
SUMÁRIO: 1 . A consulente e sua consulta. 2. O quadro factual-jurídico subjacente à consulta. 3. O quesito da consulente. 4. O Poder Judiciário brasileiro em face dos outros dois Poderes da República Federativa do Brasil. 5. A independência política e administrativo-financeira do Poder Judiciário como atributo ou prerrogativa institucional. 6. A autonomia técnica dos magistrados de per si e também dos tribunais a que vinculados. 7. A irretocável lógica estatal extrema ou de resolução definitiva das controvérsias em concreto e dos dissensos em abstrato de interesses. 8. O Poder Judiciário a fazer da jurisdição o necessário momento de estabilidade ou fixidez ou pacificação das relações jurídicas a ele submetidas. 9. Sistema de Freios e Contrapesos na esfera do Poder Judiciário e da função que o define. 9.1. A função jurisdicional em sua essência: interpretar, para imperativamente aplicar, a(s) norma(s) de Direito Positivo em sua(s) hipótese(s) de incidência e mandamento(s). 10. A edição da norma-judicial-de-decisão como simbiose do jurisdizer e do interpretar norma geral de Direito Positivo. 11. A fundamentação técnica ou objetiva ou neutra da norma-judicial-de-decisão e sua necessária extensão à estrutura binária da norma geral a aplicar. 12. O núcleo duro da função jurisdicional e seu entorno, em paralelo à função administrativa e também particular dos magistrados. 13. Reserva de Constituição versus reserva de lei complementar federal e reserva de lei complementar federal versus: a) lei ordinária igualmente federal; b) lei especial do mesmo Poder Legislativo da União. 14. Resposta ao quesito da consulente. 15. Fecho.

\section{A consulente e sua consulta}

1.1. Honra-me, com pedido de elaboração de parecer jurídico, a Associação dos Juízes Federais (AJUFE) e a Associação dos Magistrados Brasileiros (AMB). Ambas constituídas sob a forma de direito privado e com sede administrativa em Brasília-DF.

1.2. A consulta em foco traz a respeitável assinatura do próprio dirigente máximo da instituição-consulente, Juiz Federal Fernando Mendes. Já o Parecer jurídico, este me é solicitado no sentido técnico de análise tão centrada quanto objetiva de um tema de Direito; vale dizer, de um tema, ou mais de um, objeto de norma(s) de Direito Positivo. 
1.3. Mais especificamente ainda, o que me é proposto como centrado objeto de investigação teórica é a própria estrutura da fundamentação que o inciso IX do artigo constitucional de no 93 exige para a lavratura de ato decisório propriamente jurisdicional. Isto para o fim de aferição de constitucionalidade dos dispositivos da Lei Federal no 13.869/2019 que tenham por hipótese de incidência agente ou instância do Poder Judiciário no exercício da função em tela (a jurisdição em si). Dispositivos veiculadores de comandos dignificantes de sanções negativas ou de ameaça de castigo(s), por oposição, obviamente, às sanções da espécie premial ou de promessa de recompensa. Mas sanções negativas como reação estatal a determinados aspectos do ofício judicante em si. Ofício judicante ou lavratura de ato jurisdicional típico, destarte.

\section{O quadro factual-jurídico subjacente à consulta}

2.1. Passo à reprodução do quadro factual-jurídico subjacente à consulta. Isto para dar conta do meu desafio teórico de confrontar a recente Lei Federal no 13.869/2019 com o regime diretamente constitucional do Poder Judiciário brasileiro e da função que lhe empresta o nome. A pressupor o Poder Judiciário brasileiro na tríplice perspectiva que se desprende da epígrafe deste parecer jurídico, a saber:

I - O Poder Judiciário brasileiro em face dos outros dois Poderes da República;

II - Esse mesmo Poder Judiciário frente ao Sistema de Justiça que o sequencia, com imediatidade, pelo CAPÍTULO IV do TÍTULO IV da Constituição. Sistema de Justiça, a seu turno, constitucionalmente concebido e aparelhado para o desempenho "Das Funções Essenciais à Justiça". Mas "Justiça", percebe-se, no sentido objetivo de função jurisdicional do Estado brasileiro. Dando-se que: a) tal função judicante é própria de cada magistrado e de cada instância colegiada de Justiça (os tribunais superiores e o próprio STF incluídos); b) os demais agentes e instâncias de tal Sistema de Justiça existem para o desempenho de funções essenciais à jurisdição mesma. Funções essenciais ou elementares, no sentido de que, sem elas, a jurisdição não tem como ser exercida. Sem confusão ou mescla, todavia, das duas categorias jurídico-positivas: jurisdição é tão genuína atividade estatal quanto privativa 
do Poder Judiciário, enquanto as funções essenciais a ela ficam entregues ao desempenho dos membros do Ministério Público, da Defensoria Pública Federal e Estadual, da Advocacia igualmente Pública (Advocacia-Geral da União e Procuradoria da Fazenda Nacional, tanto quanto das Procuradorias dos Estados e dos Municípios, até da advocacia privada e dos Delegados de Polícia (estes últimos atuando como Política Judiciária assim da União como dos Estados).

2.2. É a matéria que passo a enfrentar, cognitivamente, já no capítulo entrante de ideias. Não sem antes esclarecer que a Lei Federal em causa traz consigo a seguinte ementa:

Dispõe sobre os crimes de abuso de autoridade; altera a Lei no 7.960 , de 21 de dezembro de 1989, a Lei no 9.296, de 24 de julho de 1996, a Lei no 8.069, de 13 de julho de 1990, e a Lei no 4.898, de 9 de dezembro de 1965; e dispositivos do Decreto-Lei no 2.848, de dezembro de 1940 (Código Penal).

\section{O quesito da Consulente}

3.1. Quanto ao quesito a que devo responder, a consulente o formula com estes dizeres:

São constitucionais os dispositivos da Lei Federal no ${ }^{\text {o }}$ 13.869/2019 que têm por hipótese de incidência agente(s) ou instância(s) do Poder Judiciário no exercício da função jurisdicional em si?

\section{O Poder Judiciário brasileiro em face dos outros dois Poderes da República Federativa do Brasil}

4.1. Pois bem, a vez primeira que o Poder Judiciário é mencionado pela Constituição é no art. $2^{\circ}$ de sua compostura enunciativa. Artigo embutido no TÍTULO atinente aos "PRINCÍPIOS FUNDAMENTAIS" e veiculador do princípio da Separação dos Poderes em bases tão independentes quanto harmônicas (sem qualquer traço de hegemonia de um sobre o outro, dessarte). 
Como é próprio, ressalte-se, do princípio republicano e do postulado jurídico dos "Freios e contrapesos" (mais abaixo comentado); porém nos marcos desta dualidade simultaneamente lógica e cronológica: a) a independência a preceder a harmonia, até porque esta última já é o resultado natural da adscrição de cada Poder a seu quadrado normativo, fale-se por esta forma); b) o Poder Legislativo a falar primeiro em nome do Estado, seguido pelo Poder Executivo e tendo no Poder Judiciário a sua embocadura ou ponto de afunilamento. Leia-se:

Art. 2ํ․ São Poderes da União, independentes e harmônicos entre si, o Legislativo, o Executivo e o Judiciário.

\subsection{Tudo tão lógico quanto cronológico, acabei de dizer, com este acréscimo de intelecção:}

I - a manifestação da imperiosa vontade jurídica do Estado brasileiro começa pelo Poder Legislativo porque: a) "ninguém será obrigado a fazer ou deixar de fazer alguma coisa senão em virtude da lei" (inciso II do art. 5 da Constituição), mas lei emanada do Legislativo mesmo, porquanto constitucionalmente referida em sentido formal e material; b) esse Poder Legislativo é tanto o da União (exercido pelo Congresso Nacional, nos termos do art. 44 da Lei Maior) quanto o que assiste às demais pessoas federadas, a cargo de uma Assembleia Legislativa, uma Câmara Legislativa e uma Câmara Municipal, segundo a precisa enunciação dos artigos constitucionais de $\mathrm{n}^{\mathrm{os}} 27,29$ e 32, respectivamente; c) o primeiro e explícito princípio regente das atividades administrativas dele, Estado, é o da "legalidade" (caput do artigo constitucional de $\mathrm{n}^{\mathrm{o}}$ 37); d) os dois primeiros conteúdos institucionais do "estado Democrático de Direito" do Brasil, que são a República e a Federação (cabeça do art. $1^{\mathrm{o}}$ da Lei Fundamental de 1988), têm no Congresso Nacional seu órgão estatal de convergência. Convergência, sim, nesta ordem: a Câmara dos deputados como representante do povo (República não é senão res publica ou coisa de todo o povo) e o Senado Federal como representante dos Estados-membros e do Distrito Federal (arts. 45 e 46, caput, da mesma Lei Fundamental brasileira). Povo que é o titular da "soberania" (primeiro princípio fundamental de que trata 
o art. $1^{\underline{0}}$ da Constituição) e fonte direta de todo o poder político, a teor deste clássico dispositivo de Direito Constitucional limpidamente democrático: "Todo o poder emana do povo, que o exerce por meio de representantes eleitos ou diretamente, nos termos desta Constituição" (parágrafo único do art. $1^{\mathrm{o}}$ );

II - essa inicial vontade jurídico-estatal é sequenciada pelos atos emanados do Executivo, Poder que, pelo seu titular (o Presidente da República) e nos termos da Constituição: a) chefia um modelo de Administração Federal que tem na lei em sentido formal e material o seu primeiro e explícito princípio; b) permanentemente gravita em torno da função legislativa federal e do seu exercente central (o Congresso Nacional), mormente na acepção de que: b-1) é tão de caráter político-eletivo quanto os próprios deputados federais e senadores (arts. 45 e 46, mais o de $\mathrm{n}^{\mathrm{o}}$ 77); b-2) sanciona, promulga e faz publicar as leis, além de baixar decretos e regulamentos para a respectiva execução (inciso IV do mesmo art. 84); b-3) inicia com exclusividade certos projetos de lei e detém o poder de vetar qualquer deles, embora a palavra final sempre caiba ao Parlamento $\left(\S 1^{\circ}\right.$ do art. 61 e $\S \S 1^{\circ}, 5^{\circ}$ e $6^{\circ}$ do art. 66 , mais o inciso $V$ do art. 84); b-4) edita medidas provisórias com força de lei (caput do art. 62); b-5) propõe emendas à Constituição, unipessoalmente (inciso II do art. 60); b-6) assina "tratados, convenções e atos internacionais, sujeitos a referendo do Congresso Nacional" (inciso VIII do art. 84); b-7) remete "mensagem e plano de governo ao Congresso Nacional por ocasião da abertura da sessão legislativa, expondo a situação do País e solicitando as providências que julgar necessárias (inciso XI do art. 84); b-8) envia "ao Congresso Nacional o plano plurianual, o projeto de lei de diretrizes orçamentárias e as propostas de orçamento previstas (...) na (...) Constituição" (inciso XXIII do art. 84); b-9) presta, "anualmente, ao Congresso Nacional (...) as contas referentes ao exercício anterior" (inciso XXIV do art. 84); b-10) provê e extingue "os cargos públicos, na forma da lei" (inciso XXV do art. 84); b-11) tem no descumprimento das leis em geral e da lei orçamentária em especial uma explícita causa de impeachment, a depender da gravidade de tal descumprimento, por óbvio (incisos VI e VII do art. 85); b-12) toma posse, ele, Chefe do Poder Executivo da União e Presidente da República, “em sessão do Congresso Nacional, prestando o compromisso de manter, defender e cumprir a Constituição, observar as 
leis, promover o bem geral do povo brasileiro, sustentar a união, a integridade e a independência do Brasil" (art. 78, cabeça);

III - nesse mesmo giro de partilha de competências entre o Poder Legislativo e o Poder Executivo, é de se reiterar que os membros de ambos os Poderes são de investidura eletiva. Investidura dependente do exclusivo exercício da soberania popular. Por isso que temporária no seu exercício e não profissionalizada. Ambiência favorável às coalizões partidárias, ideológicas e também tópicas ou ocasionais, ao menos no que se refere à adoção de políticas públicas em concreto;

IV - como tudo tem começo, meio e fim nesse mundo de dever-ser em que o Direito Positivo se traduz, tal manifestação formal da vontade jurídica do Estado segue na mesma trilha. ${ }^{1}$ Segue na kelseniana trilha de que a realidade jurídica não pode se perder no infinito ou resvalar para o interminável. Por isso que o art. $2^{\circ}$ da Constituição teria que terminar como terminou: fazendo de um dos três Poderes do Estado o ponto de afunilamento das coisas. A embocadura do Sistema de Tripartição dos Poderes (a cláusula pétrea de que versa o inciso III do $\$ 4^{\circ}$ do art. 60 dela própria, Constituição, tem o sintomático nome de "separação dos Poderes", e não de mistura ou combinação e muito menos confusão entre eles). E esse Poder extremo foi, ali, como prossegue a ser em qualquer Ordem Jurídica assim racional como civilizada e ainda democrática, o Poder Judiciário. Pelo que se pode dizer sem o menor receio de equívoco: numa democracia, assim como não se pode impedir a Imprensa de falar primeiro sobre as coisas, não se pode impedir o Judiciário de falar por último. Um Poder Judiciário que é tão politicamente independente quanto detentor de "autonomia administrativa e financeira" (art. 99, cabeça) em face dos outros dois Poderes. Além de composto por magistrados tecnicamente autônomos. Autonomia técnica em face dos outros dois Poderes, autonomia técnica endógena ou interna corporis (no âmbito do Poder Judiciário mesmo).

1 Direito Positivo que o artigo constitucional de n⿳ํㅡㄹ 127, cabeça, designa por "ordem jurídica". 


\section{A independência política e administrativo-financeira do Poder Judiciário como atributo ou prerrogativa institucional}

5.1. O caráter jurídico da independência e da autonomia administrativo-financeira do Poder Judiciário já se percebe: trata-se de prerrogativas ou atributos institucionais que se voltam para o mais facilitado e autóctone exercício das competências constitucionais dele, Poder Judiciário. Atributos e prerrogativas institucionais como reforçada situação jurídica ativa (releve-se a antieufonia) para o exercício daquelas competências diretamente a serviço de uma função pública; no caso, a função jurisdicional do Estado.

5.2. É nessa relação de imbricamento entre, de um lado, prerrogativas e competências públicas, e, de outro, competências públicas e função igualmente estatal que o Judiciário desfruta de sua independência perante os outros dois Poderes. Independência quanto à efetividade de tal função típica ou atividade-fim: a jurisdição. A significar atuação a salvo de interferência e muito menos de intervenção por parte do Legislativo e do Executivo. Para o que a Constituição confere a ele, Poder Judiciário, as complementares prerrogativas do autogoverno e da autoadministração (alínea $a$ do inciso I do art. 93). ${ }^{2}$ Mas sem deixar de prever cautelas ou antídotos ou salvaguardas para que esse atuar independente não se transmute em prepotência e desvios de todo gênero (assunto adiante desenvolvido).

\section{A autonomia técnica dos magistrados de per si e também dos tribunais a que vinculados}

6.1. Toda essa independência judiciária vai-se traduzir em autonomia para interpretar e aplicar tanto a Constituição quanto as leis e atos normativos outros. Que já é uma autonomia técnica, na medida em que: a) voltada para a revelação da vontade objetiva de tais diplomas de Direito Positivo; b) obrigatoriamente centrada na descrição da(s) hipótese(s) de incidência e

2 Art. 93. Compete privativamente:

I - aos tribunais:

a) eleger seus órgãos diretivos e elaborar seus regimentos internos, com observância das normas de processo e das garantias processuais das partes, dispondo sobre a competência e o funcionamento dos respectivos órgãos jurisdicionais e administrativos. 
do(s) mandamento(s) desses mesmíssimos diplomas; c) uma descrição que, mesmo assim objetiva, passa pelos inelimináveis aspectos subjetivos da vocação jurídica, da experiência, da responsabilidade profissional, da seriedade intelectual, da coragem e da consciência do sujeito cognoscente que atue como decididor judiciário.

6.2. É exatamente essa autonomia de ordem técnica (autonomia de quem presta a jurisdição como atividade estatal-finalística ou por definição) que assiste a todo e qualquer magistrado. Seja qual for o grau de sua jurisdição. Agindo solitariamente ou então como integrante desse ou daquele tribunal judiciário. Autonomia técnica, que imprime ganhos de funcionalidade sistêmica ou plenitude de sentido às prerrogativas institucionais da independência, do autogoverno e da autonomia administrativo-financeira do Poder Judiciário. Tema também objeto de complementares considerações teóricas mais à frente, ficando, porém, de logo assentado que ele bem se aloja no substantivo constitucional "autonomia" - assim desprovido de qualquer adjetivação - como um dos atributos jurídico-judiciários a ser tutelado pelo Conselho Nacional de Justiça (inciso I do $\S 4^{\underline{0}}$ do artigo constitucional de $\mathrm{n}^{\mathrm{o}}$ 103-B). Atributos de cada magistrado, e, por extensão, atributo de cada tribunal no exercício da função jurisdicional do Estado.

\section{A irretocável lógica da Constituição no fazer do Poder Judiciário brasileiro a instância estatal extrema ou de resolução definitiva das controvérsias em concreto e dos dissensos em abstrato de interesses}

7.1. Retomo o tópico de $n^{0} 4$ desse parecer para fincar pé na asserção de que um dos Poderes do Estado teria que falar por último. Falar imperativamente por último, a começar pela necessidade lógica e também prática de avaliar se os outros dois Poderes editaram validamente seus atos jurídicos; quer dizer, se o Legislativo elaborou suas leis nos moldes da Constituição, e se o Poder Executivo aplicou umas e outras sob os parâmetros devidos: parâmetro da lei, geralmente com imediatidade; parâmetros da Constituição, habitualmente com mediatidade. Importando lembrar que, pelo inciso VII do art. 85 da Magna Carta brasileira, é pressuposto do crime de responsabilidade incorrer o Presidente da República em falta de cumprimento das leis e das decisões judiciais. Com o que se tem um primeiro e eficaz mecanismo 
oficial de estabilidade ou fixidez ou pacificação interinstitucional-pública. Necessidade lógica e prática de se chegar a esse patamar de estabilidade ou fixidez ou pacificação das relações jurídicas também protagonizadas pelos particulares em geral ou mesmo por coletividades igualmente privadas. Explico.

7.2. Explico, prontamente, pela inquestionável afirmação de que todo Direito Positivo é constituído de normas, e que toda norma jurídica é "um imperativo autorizante" (Godofredo Teles Júnior); isto é, toda norma jurídica exprime uma endógena relação entre imperatividade (norma é determinação, ordem, comando) e exigibilidade, na clara percepção de que ela, norma jurídica, sempre autoriza ou habilita alguém a exigir em Juízo o respectivo cumprimento. Mas norma que tem por elementos ou estrutura comunicacional interna uma hipótese de incidência (ou mais de uma) e uma consequência (também uma, ou mais de uma). Descritor e prescritor normativos, como ressai desse ramo do saber que atende pela denominação de "lógica jurídica". ${ }^{3}$ Por ilustração, a regra constitucional da inviolabilidade domiciliar (inciso XI do art. 5ํㅜ) tem por hipótese de incidência a casa onde se vive, e, por mandamento, a inviolabilidade dessa residência. A da liberdade de expressão tem por hipótese de aplicabilidade (no sentido de incidência) "a atividade intelectual, artística, científica e de comunicação", posicionando-se ela, a liberdade, como parte propriamente dispositiva ou mandamental do dispositivo (inciso IX do mesmo art. $5^{\circ}$ ).

7.3. A exigibilidade da norma como garantia de sua execução, a seu turno, e para os fins deste parecer, implica o seguinte reconhecimento: à luz da Constituição brasileira, o maior de todos os direitos adjetivos-fundamentais é o de acessibilidade à jurisdição ("a lei não excluirá da apreciação do Poder Judiciário lesão ou ameaça a direito", fala o inciso XXXV do art. 5으). Uma acessibilidade tão livre quanto garantida. Sem prejuízo da enlaçada asserção de que todo ser humano, mais do que viver em "intimidade" (inciso $\mathrm{X}$ do art. 5ํㅜ da $\mathrm{CF}$ ) ou sozinho ou consigo mesmo, vive em comunhão com

3 Com todo o respeito pela célebre Teoria Tridimensional do Direito, do notável jusfilósofo brasileiro Miguel Reale, penso que o Direito é unidimensional. Unidimensional, porquanto constituído só de normas ("normas de organização, normas de competência, normas de conduta", segundo o magistério do também exponencial jusfilósofo italiano Norberto Bobbio). A norma jurídica em si é que é bidimensional: tem por elementos estruturantes dela própria uma(s) hipótese(s) de incidência e respectiva(s) consequência(s). Descritor e prescritor normativos, então, ou antecedente(s) e consequente(s) igualmente normativos. 
os outros. Vive em "privacidade" com os que lhe são caros em afeto, confiança e admiração (mesmo inciso $X$ do art. 5ำ da Constituição) e também na esfera da "sociedade" como um todo. Verbi gratia, preâmbulo da Magna Lei de 1988 e inciso I do art. 3º dela própria mais o caput do art. 194, do art. 226 e do art. 227. Donde, mais do que simplesmente viver, a pessoa dita natural convive. Necessariamente ou por imposição de sua ontologia. Da sua estrutura identitária. "Animal político" (Aristóteles) ou membro da pólis que é. E o fato é que viver assim em meio a um grupo ou, então, imerso no mais dilatado âmbito da sociedade por inteiro é tanto colaborar como se atritar. Concordância e discordância como formas elementares de interagir. Sendo que determinados dissensos instabilizam a sociedade e até comprometem a respectiva sobrevivência, equilíbrio e evolução. Sabido e ressabido que os paroxismos de desentendimentos impedem que a sociedade experimente o salto de qualidade (quântico, então) que a transforma em comunidade (se comum unidade). Não sendo por outra razão que o preâmbulo mesmo da Constituição explicita o seguinte: os seis valores da "liberdade", "segurança", "bem-estar", "desenvolvimento", "igualdade" e "justiça" - todos eles assim funcionalmente enlaçados - são "valores supremos de uma sociedade fraterna, pluralista e sem "preconceitos". Que já é, mais do que uma invertebrada ou mecânica sociedade, uma orgânica ou vertebrada comunidade, devido a que "fundada na harmonia social e comprometida, na ordem interna e internacional, com a solução pacífica das controvérsias" (ainda o preâmbulo da Lex Maxima brasileira). Solução pacífica das controvérsias - ou dos "conflitos" - que o inciso VII do art. $4^{\circ}$ da Lei Maior exigiu a "princípio" regente das relações internacionais do Brasil. Tanto quanto o substantivo "comunidade" passa a comparecer em diversas passagens do corpo normativo dela, Constituição, como, por ilustrativamente, no parágrafo único do mesmo art. $4^{\underline{0}}$ ("comunidade latino-americana de nações"), no $\S 4^{\underline{0}}$ do art. 226 ("comunidade formada por qualquer dos pais e seus descendentes") e no art. 232 ("Os índios, suas comunidades e organizações são partes legítimas para ingressar em juízo em defesa dos seus direitos e interesses, intervindo o Ministério Público em todos os atos do processo"). Saltando à evidência que a diferença entre sociedade e comunidade é a mesma diferença de qualidade entre casa e lar (ninguém jamais viu, na fachada de uma residência, placa de "vende-se este lar", ou de "casa, doce casa"). ${ }^{4}$ 4 Apropriadamente, assentou Rui Barbosa que "a Nação" (comunidade maior no âmbito
interno de um Estado soberano) "é a família amplificada". 


\section{O Poder Judiciário a fazer da jurisdição o necessário momento de estabilidade ou fixidez ou pacificação das relações jurídicas a ele submetidas}

8.1. A conclusão é uma só: o art. $2^{0}$ da Constituição não rende ensejo a dúvida hermenêutica: o Poder Judiciário brasileiro é o que fala por último, imperativamente. Poder Extremo, por conseguinte. $\mathrm{O}$ derradeiro Poder a que se pode recorrer para fazer valer esse ou aquele direito de quem a ele recorre. E falar por derradeiro é dar a última, decisiva e garantida palavra jurídica. O que já significa pacificar, estabilizar, pôr fim aos dissensos, com a mesma força heterônoma da lei; ou seja, com a força de emitir um comando estatal que não tem sua juridicidade dependente da autonomia de vontade dos respectivos destinatários (efetividade normativa é outra coisa!), o que implica distinguir estabilizar de moderar. Moderar, claro, naquele proverbial ou apenas interesseiro sentido de acomodar as coisas, atender a conveniências (sempre momentâneas ou passageiras) que nada têm a ver com a vontade objetiva dessa ou daquela norma jurídica. Mistura tóxica de judicatura e política, esta última a capturar a primeira quase que invariavelmente.

8.2. A esse empoderamento do Poder Judiciário no exercício da jurisdição, todavia, vai corresponder um regime diretamente constitucional de salvaguardas. De multifacetados antídotos ou cautelas assim matricialmente constitucionais; ora no interior das próprias instâncias judiciárias, ora no exterior dessas esferas judicantes. Antídotos ou salvaguardas ou cautelas que fazem parte, justamente, do esquema de Freios e Contrapesos com que a Constituição brasileira intenta equilibrar as coisas do Direito em geral e do princípio da Tripartição dos Poderes em especial. Avultando o entendimento de que:

I - nos contrapesos é que se dá o teórico equilíbrio entre as competências e prerrogativas dos Poderes. Nenhum deles, pelo tamanho do seu quinhão constitucional, a se colocar hegemonicamente perante os outros. Balizamento exógeno ou interinstitucional das coisas, então;

II - nos freios, por outro lado, é que se dá o balizamento endógeno ou intrainstitucional, pois o que se pretende com eles é impedir tanto o desvio quanto a exacerbação no exercício das competências 
e prerrogativas de cada Poder. Mecanismo interna corporis de contenção em certos limites e balizas, que termina sendo um dever de autocontenção;

III - na esfera mesma do Poder Judiciário, o dever de observância de tais balizas e limites é que responde por um regime diretamente constitucional de compostura binária: a) um regime recursal ou de possibilidades de modificação de uma determinada norma-judicialde-decisão, que, para isso, ele, Judiciário, se estrutura em escalonados graus ou instâncias superpostas de jurisdição e atua sob o permanente escrutínio de um Sistema de Justiça (arts. 127 a 135 mais o inciso IV e o $§ 4^{\circ}$ do art. 144) de que também fazem parte o Ministério Público, as Defensorias Públicas, a Advocacia Pública e também privada, além dos órgãos de Segurança Pública no desempenho das atividades de Polícia Judiciária (Sistema encimado pelo Judiciário mesmo, é certo, mas sem nenhuma hierarquia sobre os demais agentes e instituições); b) um regime propriamente sancionador ou punitivo, a incorporar os institutos das infrações disciplinares, das infrações penais comuns (dentre elas os crimes contra a Administração Pública), dos crimes de responsabilidade e do "abuso de poder" ou, então, de "autoridade", na linguagem mesma da Constituição, como se lê nos incisos LXVIII e LXIX do art. $5^{\circ}-$ a propósito do habeas corpus e do mandato de segurança - e no inciso IV do art. 103-B, alusivo às competências do Conselho Nacional de Justiça. Conselho alçado à condição de órgão público de controle para o desempenho de competências desta envergadura: a) a de controlar a "atuação administrativa e financeira do Poder Judiciário" (...) e o "cumprimento dos deveres funcionais dos juízes"; c) a de "zelar pela observância do art. 37 e apreciar, de ofício ou mediante provocação, a legalidade dos atos administrativos praticados por membros ou órgão do Poder Judiciário, podendo desconstituí-los, revê-los ou fixar prazo para que se adotem as providências necessárias ao exato cumprimento da lei, sem prejuízo da competência do Tribunal de Contas da União"; d) a de "receber e conhecer das reclamações contra membros ou órgãos do Poder Judiciário, inclusive contra seus serviços auxiliares, serventias e órgãos prestadores de serviços notariais e de registro que atuem por delegação do poder público ou oficializados, sem prejuízo da competência disciplinar e correcional dos tribunais, podendo avocar processos disciplinares em curso e 
determinar a remoção, a disponibilidade ou a aposentadoria com proventos proporcionais ao tempo de serviço e aplicar outras sanções administrativas, assegurada ampla defesa; e) a de "representar ao Ministério Público, no caso de crime contra a administração pública ou de abuso de autoridade"; f) a de rever, ofício ou mediante provocação, os processos disciplinares de juízes e membros de tribunais julgados há menos de um ano; ${ }^{5}$

8.3. Em rigor de Ciência (penso), tais mecanismos de Freio e Contrapesos servem, primeiramente, para indicar os campos da atividade essencial ou atividade-fim de cada Poder estatal. $\mathrm{O}$ que vai corresponder à função típica de cada qual deles, porque Separação de Poderes é... separação de funções estatais básicas. Nenhum Poder orgânico do Estado a atuar fora do seu quadrado normativo-funcional. Fora da função central que lhe empresta o nome para invadir espaço alheio. Já a segunda serventia do Sistema em causa (o dos Freios e Contrapesos), reside ela na própria conceituação ou definição de cada qual dessas funções nucleares. No dizer em que se traduz (significativa ou intelectivamente, então) cada função estatal básica em face das demais. Por derradeiro, serve ele (Sistema ou mecanismo de Freios e Contrapesos) para infletir a distinção entre o que há de central e o que há de lateral no exercício das funções de que venho falando. Núcleo duro versus entorno da atividade, por consequência. É o desafio temático a que passo com imediatidade, mas limitadamente ao objeto da consulta, de pronto esclareço.

\section{Sistema de Freio e Contrapesos na esfera do Poder Judiciário e da função que o define}

\subsection{A função jurisdicional em sua essência: interpretar, para imperativamente aplicar, a(s) norma(s) de Direito Positivo em sua(s) hipótese(s) de incidência e mandamento(s)}

9.1.1. Bem, ao falar que "todos os julgamentos dos órgãos do Poder Judiciário serão públicos, e fundamentadas todas as decisões, sob pena de nulidade $(. . .)^{\prime \prime}$, o inciso IX do art. 93 da Constituição já estabelece o elo funcional entre

5 Incisos I a V do artigo constitucional de $\mathrm{n}^{\mathrm{o}}$ 103-B, sem os caracteres negritados. 
ele, Poder Judiciário, e o ato de julgar. $\mathrm{O}$ julgamento como função típica ou atividade-fim, o Poder Judiciário como organismo ou aparato-meio. $\mathrm{O}$ ato de julgar tanto a se distinguir do ato de legislar quanto dos outros atos a que dão imediata execução à lei; seja na esfera política, seja na esfera administrativa (esta a merecer o diferenciado tratamento que se lê no inciso do mesmo artigo), ${ }^{6}$ seja, ainda, na esfera totalmente privada. E julgamento, reitere-se:

\section{I - como exercício de "função jurisdicional do Estado" ou "JUSTIÇA" em sentido objetivo. Aqui, de acordo com a própria nomenclatura do CAPÍTULO IV DO TÍTULO IV (“DAS FUNÇÕES ESSENCIAIS À JUSTIÇA"). Ali, consoante o caput do art. 127 ("O Ministério Público é instituição permanente, essencial à função jurisdicional do estado (...)". Intelecção já antecipada pelo inciso XII do citado artigo constitucional de $\mathrm{n}^{\mathrm{o}} 93$, ao falar que "a atividade jurisdicional será ininterrupta (...)". E ininterrupta, por aquela mencionada razão de que o acesso ao Poder Judiciário é o principal direito subjetivo-processual. A principal das garantias fundamentais de que trata o art. $5^{\circ}$ da Constituição, justificar a parêmia da proibição do juízo de non liquet (vedação de não liquidação do tema ou do caso sub judice, que também se expressa no chamado princípio da inafastabilidade da jurisdição);}

II - como geminada atuação processar e julgar, pois entre as salvaguardas medularmente constitucionais que cercam o julgamento em sentido típico ou específico está "o devido processo legal" (inciso LV do art. $5^{\circ}$ ). Mais do que isso, um devido processo legal que vai compor com duas outras garantias processuais-constitucionais imediatamente anteriores uma tríade normativa de mais forte inter-referência funcional (relação de feedback ou de retroalimentação operativa), a saber: a) "ninguém será processado nem sentenciado senão pela autoridade competente"; b) "ninguém será privado da liberdade ou de seus bens sem o devido processo legal"; c) "aos litigantes, em processo judicial ou administrativo, e aos acusados em geral, são assegurados o contraditório e a ampla defesa, com os meios e recursos a ela inerentes" (ampla defesa que já confere a tal garantia a força de um devido processo

6 Inciso X do art. 93, litteris: “as decisões administrativas dos tribunais serão motivadas e em sessão pública, sendo as disciplinares tomadas pelo voto da maioria absoluta de seus membros". 
legal-substitutivo ou de franca possibilidade de influência das partes e interessados privados na prolação do decisum). Todos enunciados pelo art. 5으, incisos LIII, LIV e LV, respectivamente. Donde ela própria, Constituição, falar das competências do Supremo Tribunal Federal e do Superior Tribunal de Justiça como típicas atividades de "processar e julgar" (inciso I do art. 102 e inciso I do art. 105, nessa ordem).

9.1.2. Esse complexo ato de julgar ("processar e julgar") como função específica ou atividade-fim do Poder Judiciário não é senão editar uma norma-dedecisão. Uma norma-judicial-de-decisão. Norma como imperativo ou determinação (como é próprio de toda norma editada por autoridade do Sistema Jurídico). Com a diferença de que se cuida da norma individual, particular e concreta, por oposição à norma-lei em sentido material: que é norma tão geral quanto impessoal e abstrata, segundo a insuperável doutrina de Hans Kelsen. ${ }^{7}$ Mas a norma-judicial-de-decisão como o desempenho em si da função jurisdicional típica, nunca é demasiado repetir. Norma fundamentada (por direta imposição constitucional), que é norma revelada por interpretação técnica daquela materialmente legislativa. Uma interpretação eminentemente técnica ou objetiva ou neutra, ajunte-se, para que a vontade subjetiva do intérprete não tome jamais o lugar da vontade objetiva da norma geral interpretada (exigência de neutralidade operativa). ${ }^{8}$

\subsubsection{Convém reprisar: a norma-judicial-de-decisão é norma de aplicação da}

lei em sentido material. Aqui embutida a própria Constituição como a norma jurídica de maior grau de generalidade, impessoalidade e abstratividade. Dando-se que o ato de aplicação judicial da norma em sentido material (norma-Constituição, norma-legal ou, então, a ela equiparada) somente se operacionaliza pela interpretação desta última. Uma coisa a acarretar outra, como explico já no capítulo seguinte.

7 A generalidade como atributo normativo que se traduz no maior alcance possível de ações. A impessoalidade, como pretensão igualmente normativa de abarcar o máximo de destinatários (sujeitos de Direito). A abstratividade, enfim, a ter como traço distintivo o renovar por forma perene (ou pelo menos duradouramente) o vínculo funcional entre hipótese(s) de incidência e mandamento(s).

8 "O universo não é uma ideia minha. A minha ideia do universo é que é uma ideia minha", disse Fernando Pessoa. O que enseja ao estudioso do Direito fazer a paródia de que $A$ norma não é uma ideia minha. A minha ideia de norma é que é uma ideia minha. A norma, aqui, na objetiva condição de Direito-lei ou, então, de Direito-Constituição. 


\section{A edição da norma-judicial-de-decisão como simbiose do jurisdizer e do interpretar norma geral de Direito Positivo}

10.1. Deveras, não há como separar ato judicial de aplicação de norma constitucional ou, então, de norma legal e o ato de interpretar qualquer delas (a Constitucional, a legal e a veiculada por ato normativo equiparável à lei). Trata-se de uma só realidade: a norma-judicial-de-decisão é a própria consubstanciação da interpretação jurídica ultimada. A interpretação final de norma constitucional e da lei infraconstitucional é a jurisdição mesma que se presta num processo judicial de feição objetiva ou abstrata, ou num processo de feição subjetiva ou em concreto. Afinal, jurisdizer vem de jurisdictio, e jurisdictio é tanto dicção do Direito quanto ação de ministrar justiça. Em última análise, jurisdictio é revelar, em processo judicial, o conteúdo significante da norma geral interpretada. O quê dessa norma em sua dúplice estrutura de hipótese de incidência e mandamento, pois Direito é norma, bloco de normas, todo um sistema de normas, pois somente de norma(s) ele é constituído. ${ }^{9}$

10.2. Na busca da objetiva revelação de tal conteúdo significante é que se homizia o cerne ou a medula da atividade/função jurisdicional. Seu núcleo duro. Aquela dimensão do labor propriamente judicial que somente pela Constituição é conformada. Reserva de Constituição, entretanto, que não prevalece para as atividades de entorno da jurisdição (aspectos laterais ou situados na franja da atividade-fim de julgar), como intento demonstrar no tópico de $\mathrm{n}^{\mathrm{o}} 11$ deste parecer. Isso porque, antes, parto para um reforço de entendimento do tema que me parece merecedor de tratamento em capítulo próprio.

9 Essa geminação entre processar e julgar, de uma banda, e julgar e interpretar norma geral, de outra, é daquela mesma ontologia que preside a relação entre enunciado normativo-geral e sua vernacular leitura. Donde Paulo de Barros Carvalho ensinar que o chamado método literal de interpretação jurídica é, no fundo, um pressuposto de interpretação: só se pode interpretar um texto legal, ou constitucional, lendo-o. 


\section{A fundamentação técnica ou objetiva ou neutra da norma-judicial-de-decisão e sua necessária extensão à estrutura binária da norma geral a aplicar}

11.1. Esse reforço de entendimento do tema é para deixar ainda mais claro que fundamentar objetiva ou técnica ou neutralmente uma norma-judicial-de-decisão é fazê-lo na perspectiva de toda a estrutura binária da norma geral a aplicar assim por via jurisdicional. Em palavras outras: a norma geral a aplicar pela norma-judicial-de-decisão é a norma que se contém nesse ou naquele dispositivo em que se decompõe a legiferação constitucional ou, então, legal (mais o ato normativo com forma de lei): artigos parágrafos, incisos, alíneas, números... Logo, sob a encarecida estrutura de hipótese de incidência e mandamento. A que se agregam as seguintes asserções:

I - o dispositivo a aplicar tanto pode conter uma norma inteira quanto um fragmento de norma e, ainda, uma pluralidade delas. Ilustro com o próprio corpo de dispositivos da Constituição: a) o caput do art. $1^{\text {o }}$ contém apenas uma das características nodulares da Federação, que é a indissolubilidade, pois a característica da autonomia somente é referida no art. 18, cabeça; b) já o inciso XXX do art. 5º esse veicula uma norma inteira, que é da garantia do direito de herança; c) finalmente, a pluralidade de normas que se lê na cabeça do mesmo art. 5o, sob a seguinte dicção: “Todos são iguais perante a lei, sem distinção de qualquer natureza, garantindo-se aos brasileiros e estrangeiros residentes no País a inviolabilidade do direito à vida, à liberdade, à igualdade, à segurança e à propriedade $(. . .)^{\prime \prime}$. Vida biopsíquica e anímica, sim, porém em condições de liberdade; em condições de igualdade; em condições de segurança; em condições de propriedade, tudo nos termos em que esse emblemático art. $5^{\circ}$ se desdobra;

II - a norma-de-legiferação é filha de um legislador (assim o constituinte como o constituído, mesmo que este se ponha como editor de emenda constitucional), mas uma filha que já nasce emancipada quanto ao seu significado. Emancipada ou autonomizada significativamente em face da sua matriz institucional, porquanto dotada de uma vontade normativa tão objetiva quanto própria (o intérprete não é um psicanalista do legislador, porém da lei, sempre recordava Geraldo Ataliba); 
III - é essa norma-de-legiferação, justamente, que abriga uma mensagem, um conteúdo tão vernacular quanto significante. Inteligível. O próprio quê de significatividade em que se traduz seu núcleo duro. Daí a distinção (mais uma) entre o significado e o sentido dessa ou daquela norma geral. O significado a emergir da pergunta sobre o encarecido quê: qual o quê da norma a aplicar pelo magistrado enquanto magistrado mesmo? O sentido este é o que vai resultar da resposta que se possa dar quanto ao porquê e ao para quê da mesma forma. Razão-de-ser e finalidade(s) normativas, pela ordem.

11.2. Que a norma-judicial-de-decisão tenha que ser fundamentada já foi aqui muitas vezes afirmado, a partir da referência ao inciso IX do art. 93 da Constituição. Que essa fundamentação seja técnica ou objetiva ou rigorosamente neutra também já foi dito e reiterado, por incidir sobre norma geral-constitucional, ou norma-geral de caráter legal, ou a esta última equiparável. Agora, o que se busca neste capítulo é o mencionado reforço de entendimento: a tecnicalidade ou objetividade ou neutralidade operativa da fundamentação somente se perfaz com o reconhecimento de que as mencionadas normas gerais hão de ser consideradas na sua estrutura binária de hipótese de incidência e mandamento (descritor e prescritor, antecedente e consequente normativos, como dantes esclarecido). Recaindo sobre esses dois elementos a exegese ou interpretação do decididor judiciário. Da instância judiciária processante assim da ação de perfil abstrato (objetivo) como da ação de perfil concreto (subjetivo). Com o que se tem a estrutura mesma da fundamentação em sentido substantivo. A estrutura em si do ato judicial de fundamentar uma decisão (sem ingerência de quem quer que seja) corresponde àquela parte do meio da estrutura apenas em sentido formal (relatório, fundamentação e parte dispositiva ou deliberativa).

11.3. Mas aqui nesta altura das reflexões que venho tecendo, e em consideração mesma à jurisdição que tem por característica recair sobre as ações instauradoras de processo abstrato ou de perfil tão somente objetivo (ADINS, ADEC, ADPF), ${ }^{10}$ devo porfiar no entendimento de que se contém no conceito de norma geral, além dos dispositivos constitucionais, todo ato normativo que se revista da força de modificar primariamente a Ordem Jurídica.

10 Ação Direta de Inconstitucionalidade, Ação Direta de Inconstitucionalidade por Omissão, Ação Declaratória de Constitucionalidade, Ação de Descumprimento de Preceito Fundamental. 
O advérbio "primariamente" na acepção de primeira mente ou logo abaixo da Constituição. Sabido que ela, Constituição, mais do que primariamente inovar a Ordem Jurídica de um povo soberano, funda essa Ordem. Funda ou inaugura ou instaura uma Ordem Jurídica absolutamente ex novo.

\section{O núcleo duro da função jurisdicional e seu entorno, em paralelo à função administrativa e também particular dos magistrados}

12.1. Não cessa por aqui o esquema das distinções analíticas a que este parecer deve obediência por seriedade intelectual de quem o subscreve. Por isso que trago à baila três novas diferenciações:

I - diferenciação entre núcleo duro da norma-judicial de decisão e circunstâncias em que proferida tal decisão. Circunstâncias ou entorno dela, norma-judicial-de-decisão. O núcleo duro, hospedado no entendimento judicial da norma geral a aplicar. Entendimento a que se chega por livre interpretação da(s) hipótese(s) de incidência e do(s) mandamento(s) normativo(s), tradutores de uma imperiosa mensagem (mensagem inteira, fragmentária ou múltipla) de Direito legislado; isto é, de Direito-Constituição em sentido material. Já o entorno ou as circunstâncias em que manifestado tal entendimento judicial, a se hospedar ali nas respectivas condições de modo, tempo e lugar. Aspectos periféricos à decisão ou em torno dela, portanto, de que servem de amostragem os seguintes: presteza/morosidade, insuspeição/suspeição, impedimento/desimpedimento, decoro/despudor, segurança/insegurança, trato respeitoso/trato autoritário das partes e dos seus representantes, planejamento/improvisação das sessões e julgamento, assiduidade/absenteísmo, discrição/espalhafato, zelo/desmazelo (da indumentária à gramática), apartidarismo/partidarismo;

II - diferenciação entre atividade-fim dos juízes (jurisdição propriamente dita) e atividade-meio ou simplesmente administrativa. O magistrado a praticar atos administrativos, a latere da sua atuação como juiz mesmo. Hipótese colocada em realce pelo citado $\S 4^{\underline{0}}$ do art. 103-B da Constituição, ao inserir nas competências do Conselho 
Nacional de Justiça "o controle de atuação administrativa e financeira do Poder Judiciário e (...) o cumprimento dos deveres funcionais dos juízes", também na perspectiva da "observância do art. 37" dela, Constituição, e da "legalidade dos atos administrativos praticados por membros ou órgão do Poder Judiciário (...)";

III - diferenciação entre qualquer das atividades anteriores e aquelas que o magistrado protagoniza como indivíduo ou, então, cidadão comum.

12.2. É deste ponto de apropriação cognitiva do tema central a que me propus analisar que se desprende mais uma fundamental distinção: o entendimento judicial quanto ao núcleo duro da norma geral a aplicar é de regime direta e exclusivamente constitucional. É de reserva de Constituição. Diversamente, ficam disponibilizados para conformação por via de lei infraconstitucional: a) aqueles aspectos laterais ou periféricos a tal norma-judicial-de-decisão; b) os atos administrativos que esse ou aquele magistrado venha a praticar enquanto administrador público mesmo; c) os atos de autoria de qualquer juiz como pessoa natural ou indivíduo mesmo.

12.3. Inicialmente, é a distinção entre o juiz que fica por inteiro no espaço da jurisdictio... e o juiz que não fica (hipótese, esta última, da atividade apenas situada no entorno ou franja ou órbita da atividade-fim do Poder Judiciário). Depois, o juiz que sai totalmente desse espaço para atuar: a) como administrador público igual a qualquer outro; b) como indivíduo também igual a outro qualquer. Matéria que serve de recheio ao capítulo imediato, até porque acrescida de um quarto tipo de malfeitoria jurídica, porém de regime normativo dual: o crime de responsabilidade de certos magistrados.

\section{Reserva de Constituição versus reserva de lei complementar federal e reserva de lei complementar versus: a) lei ordinária igualmente federal; b) lei especial do mesmo Poder Legislativo da União}

13.1. Com efeito, a própria Constituição é que fala de malfeitorias jurídicas dos magistrados. Malfeitorias passíveis de classificação em quatro modalidades, a 
saber: a) "infrações penais comuns" (alínea $c$ do inciso I do art. 102) ou "crimes comuns" (alínea $a$ do inciso I do art. 105); b) "crimes de responsabilidade" (de novo, alínea $c$ do inciso I do art. 102 mais a alínea $a$ do inciso I do art. 105 e alínea $a$ do inciso I do art. 108); c) "crime contra a Administração Pública" (inciso IV do $\S 4^{\circ}$ do art. 103-B); d) "abuso de autoridade" (mesmo inciso IV do $\S 4^{\underline{o}}$ do art. 103-B). Todos esses dispositivos precedidos de norma igualmente constitucional que insere nas competências dos "Tribunais de Justiça julgar os juízes estaduais e do Distrito Federal (...) nos crimes comuns e de responsabilidade" (inciso III do art. 96). Isso de permeio: a) com a previsão da reabertura de processos disciplinares contra "juízes e membros de tribunais julgados há menos de um ano"; 11 b) com o estabelecimento de inconfundíveis regimes normativos para os citados ilícitos, conforme a classificação que empreendo no curso deste mesmo bloco temático. Mas ilícitos (todos eles) a se dar do lado de fora da estrutura da fundamentação da norma-judicial-de-decisão, porquanto constitucionalmente qualificada como expressão da autonomia técnica de cada magistrado. Sob regime constitucional tão direto quanto exclusivo. E definitivamente significante da própria demonstração do ato de apreender cognitivamente o descritor e o prescritor da norma geral a aplicar. Descritor como antecedente(s) ou hipótese(s) de incidência de uma vez por todas. Desde que se tenha como paradigmas de norma geral tanto a Constituição quanto as leis, ou, então, ato normativo que se adote da força de modificar primariamente a Ordem Jurídica (ressalva mais acima feita).

13.2. Vou aos citados regimes jurídicos das ilicitudes perpetradas por magistrados de qualquer das quatro instâncias do Poder Judiciário: a) instância ordinária, abarcante dos juízes do $1^{0}$ grau e respectivos tribunais; b) instância superior, consubstanciada no Superior Tribunal de Justiça, no Tribunal Superior do Trabalho, no Tribunal Superior Eleitoral e no Superior Tribunal Militar; c) instância extraordinária, corporificada no Supremo Tribunal Federal (que também opera como Corte Constitucional de Justiça para o processo e julgamento das ações de perfil objetivo ou abstrato). Regimes jurídicos ou modos normativos de ser, que passo a retratar por este modo esquemático:

I - o regime da lei ordinária federal para as "infrações penais comuns" ou, simplesmente, "crimes comuns" ("não há crime sem lei anterior

11 Inciso $\mathrm{V}$ do $\S 4^{\mathrm{o}}$ do art. 103-B. 
que o defina, nem pena sem prévia cominação legal", consoante a fundamental regra do inciso XXXIX do art. 5o da Constituição). Entendido que o magistrado, aqui, age como indivíduo. Igual, portanto, a qualquer outra pessoa natural. Debaixo da norma igualmente constitucional do caput do art. 5º, segundo a qual “Todos são iguais perante a lei, sem distinção de qualquer natureza (...)". Logo, o membro do Poder Judiciário como locador, locatário, condômino, proprietário, vizinho, condutor de veículo, correntista, pai, filho, marido, namorado, pessoa solteira, religioso, ateu... e coisas do gênero;

II - o mesmo regime da lei ordinária federal para o(s) "crime(s) contra a administração Pública", mesmo que embutidos no Código Penal, visto que somente cometido(s) pelo magistrado como administrador público. Ou como servidor público em sentido lato. Não como juiz-juiz. Por isso que é de ser tratado em paridade de condições com os demais administradores, ou com os agentes estatais comuns;

III - o regime da Lei Complementar que a própria Constituição nominalmente requesta para a veiculação do Estatuto da Magistratura (art. 93, cabeça), no que toca aos atos constitutivos de "abuso de autoridade". Abuso de autoridade e infrações em que o magistrado venha a incorrer no exercício do seu cargo mesmo, como a falta disciplinar e o "descumprimento de deveres funcionais" (deveres que têm por contraponto direitos das partes e/ou dos seus advogados). Explicado que tais infringências são aquelas que se dão no exercício do cargo, sim, mas não da função; mas não da função ali no que ela tem de exclusivamente jurisdictio: dicção do Direito e ato de administrar a justiça, por modo tecnicamente autônomo. Dizer o Direito aplicável à tese ou, então, ao caso como forma de distribuir justiça. Núcleo duro, e não apenas em torno desse núcleo, pois no ortodoxo ou típico ou finalístico exercício do seu ofício judicante o magistrado apenas se expõe às medidas/ações/recursos de uma instância jurisdicional para outra de superior grau de decisão. Assim, o magistrado singularmente considerado como essa ou aquela instância colegiada. Os ilícitos, então, a se dar do lado de fora da estrutura da fundamentação da norma-judicial-de-decisão, porquanto constitucionalmente qualificada como expressão da autonomia técnica de cada magistrado. Sob regime constitucional 
tão direto quanto exclusivo. E definitivamente significante da própria demonstração do ato de apreender cognitivamente o descritor e o prescritor da norma geral a aplicar. Avultando a lembrança de que essa dualidade núcleo duto/entorno do decisum também tipifica a liberdade de imprensa, nos precisos termos do acórdão proferido pelo STF na $\mathrm{ADPF} \mathrm{n}^{\mathrm{0}}$ 130. Acórdão que deixou claramente posto que as relações nucleares ou centrais ou ortodoxamente de imprensa estão a salvo de conformação legislativa infraconstitucional. Somente as relações secundárias ou periféricas ou laterais de imprensa é que deixam de ser constitutivas de reserva de Constituição, assujeitando-se, por conseguinte, àquela conformação legislativa simplesmente legal;

IV - o regime tanto constitucional-direto quanto o da Lei Especial $\mathrm{n}^{\mathrm{o}}$ 1.079, de 10 de abril de 1950, atinentemente ao "crime de responsabilidade". Lei Federal monotemática, então, porém com essa particularidade: somente incluiu no seu âmbito subjetivo de incidência os ministros do STF (art. 39). Ainda assim, apanhando-os pelo ângulo externo daquela estrutura de fundamentação técnica ou jurisdicional propriamente dita. Confira-se:

Art. 39. São crimes de responsabilidade dos Ministros do Supremo Tribunal Federal:

"1 - alterar por qualquer forma, exceto por via de recurso, a decisão ou voto já proferido em sessão do Tribunal" (o ato de alterar é que é criminalidade, e não o fundamento em si da decisão);

"2 - proferir julgamento, quando, por lei, seja suspeito na causa" (de novo, causa da incriminação é apenas a suspensão);

"3 - exercer atividade político-partidária" (a toada não muda, pois o exercício da atividade partidária é que se põe como conduta vedada, e não o conteúdo da decisão);

"4 - ser patentemente desidioso no cumprimento dos deveres do cargo" (também aqui, a patente desídia ou o flagrante desleixo é que se faz atividade criminosa, o que nada tem a ver com o núcleo duro do decisum);

"5 - proceder de modo incompatível com a honra e decoro de suas funções" (quinto e último proceder que a lei incrimina, porém apenas situado no entorno da decisão em sentido técnico); 
"Art. 39-A. Constituem, também, crimes de responsabilidade do Presidente do Supremo Tribunal Federal ou de seu substituto quando no exercício da Presidência, as condutas previstas no art. 10 desta Lei, quando por eles ordenadas ou praticadas" (que são condutas praticadas "contra a lei orçamentária", e não como expressão da jurisdictio).

\section{Resposta ao quesito da consulente}

14.1. Chego, enfim, à fase da resposta ao quesito da consulente. Resposta que passo a ministrar em face dos enunciados com que a Lei Federal Ordinária n $13.869 / 2019$ define o crime de abuso de autoridade... no exercício da função jurisdicional do Estado. Dispositivos, assim, que se unificam por apanhar o magistrado como prolator de medida ou decisão propriamente judicial. Mas assim fazendo (a lei) para fugir do acervo constitucional das medidas/ações/ recursos de uma instância judicial a outra e passar a criminalizar o decididor nas hipóteses que avançam. Criminalização e penalização - agrego - de uma só cajadada. Com o que, antecipo, incidem em inconstitucionalidade formal e material a um só tempo.

14.2. Como se verá da transcrição que faço mais abaixo, tais dispositivos têm mesmo em comum: a) pressupor o exercício da atividade judicante em sentido técnico; b) interferir no espaço da autonomia técnica do magistrado para conhecer da(s) hipótese(s) e mandamento(s) da norma geral a aplicar por ele; c) criminalizar como abuso de autoridade a interpretação que o magistrado fizer em desacordo com o prefigurado em cada um desses dispositivos. Com o que entram em rota de colisão mortal com o regime constitucional da matéria, acima descrito e assim resumido:

I - nenhum diploma jurídico infraconstitucional pode ter a pretensão de ditar as coordenadas mentais do juiz-juiz, ou instância judicante colegiada, para conhecer do descritor e do prescritor dessa ou daquela norma geral a aplicar por forma tipicamente jurisdicional. Isso porque a autonomia técnica do magistrado ou, então, da instância judicial colegiada é imperativo tão direta quanto exclusivamente constitucional, pois se faz de condição e ponto de afunilamento operacional da independência política e das prerrogativas de autogoverno e de autoadministração do Poder Judiciário; 
II - cuidando-se de norma geral versante sobre o exercício da função jurisdicional, o que não se contiver na concreta cognição do núcleo duro ou medular dessa norma (hipótese[s] de incidência e mandamento[s]) e mandamento(s) já se constitui em entorno do decisum. Já se inscreve no quadro das circunstâncias de modo, tempo e lugar da prolação em si do ato decisório. Nessa medida, somente pelo Estatuto da Magistratura é de ser conformado, principalmente para o fim de configuração da falta de cumprimento dos deveres desse ou daquele magistrado. $\mathrm{O}$ que exige a edição de Lei Complementar Federal, e o fato é que a Lei no 13.869/2019 é apenas de caráter ordinário.

14.3. Faço a transcrição dos dispositivos em causa que tenho como inconstitucionais por ambos os prismas de análise jurídica: o material e o formal. Mas uma transcrição já desacompanhada de qualquer outra consideração de mérito, salvo a pertinente à interlocução dos magistrados com os profissionais da advocacia. É que os advogados, essenciais que são à função jurisdicional do Estado, também desfrutam de prerrogativas diretamente constitucionais. Dentre elas a conformação do seu labor profissional por lei federal especial: o "Estatuto da Advocacia e a Ordem dos Advogados do Brasil (OAB)". ${ }^{12}$ Ainda assim, entendo que o tema se inscreve nos concomitantes princípios da reserva de Constituição e da Lei Complementar veiculadora do Estatuto da Magistratura. Cabendo à Lei da Advocacia aportar outros meios de conciliar a aplicabilidade dos dois orgânicos diplomas, porém sem criminalizar a interpretação judicial dessa ou daquela norma geral (o inconcebível crime de hermenêutica). Ei-los:

Art. 9o. Decretar medida de privação da liberdade em manifesta desconformidade com as hipóteses legais:

Pena - detenção, de 1 (um) a 4 (quatro) anos, e multa.

Parágrafo único. Incorre na mesma pena a autoridade judiciária que, dentro do prazo razoável, deixar de:

I - relaxar a prisão manifestamente ilegal;

${ }^{12}$ Lei Federal no 8.906 , de 4 de julho de 1994. 
II - substituir a prisão preventiva por medida cautelar diversa ou de conceder liberdade provisória, quando manifestamente cabível;

III - deferir liminar ou ordem de habeas corpus, quando manifestamente cabível.

Art. 10. Decretar a condução coercitiva de testemunha ou investigado manifestamente descabida ou sem prévia intimação de comparecimento ao juízo:

Pena - detenção, de 1 (um) a 4 (quatro) anos, e multa.

Art. 20. Impedir, sem justa causa, a entrevista pessoal e reservada do preso com seu advogado:

Pena - detenção, de 6 (seis) meses a 2 (dois) anos, e multa.

Parágrafo único. Incorre na mesma pena quem impede o preso, o réu solto ou o investigado de entrevistar-se pessoal e reservadamente com seu advogado ou defensor, por prazo razoável, antes de audiência judicial, e de sentar-se ao seu lado e com ele comunicar-se durante a audiência, salvo no curso de interrogatório ou no caso de audiência realizada por videoconferência.

Art. 25. Proceder à obtenção de prova, em procedimento de investigação ou fiscalização por meio manifestamente ilícito:

Pena - detenção, de 1 (um) a 4 (quatro) anos, e multa.

Parágrafo único. Incorre na mesma pena quem faz uso de prova, em desfavor do investigado ou fiscalizado, com prévio conhecimento de sus ilicitude.

Art. 36. Decretar, em processo judicial, a indisponibilidade de ativos financeiros em quantia que extrapole exacerbadamente o valor estimado para a satisfação da dívida da parte e, ante a demonstração, pela parte, da excessividade da medida, deixar de corrigi-la: 
Pena - detenção, de 1 (um) a 4 (quatro) anos, e multa.

Art. 43. A Lei no 8.906, de 4 de julho de 1994, passa a vigorar acrescida do seguinte art. $7^{\mathrm{o}}-\mathrm{B}$ :

'Art. 7º-B. Constitui crime violar direito ou prerrogativa de advogado previstos nos incisos II, III, IV e V do caput do art. $7^{\circ}$ desta Lei:

Pena - detenção, de 3 (três) meses a 1 (um) ano, e multa."'

\section{Fecho}

Este o meu parecer, data vênia de entendimento contrário.

Brasília (DF), 25 de outubro de 2019

Carlos Ayres Britto

OAB/DF nº 40.040 